\title{
Radiographic evaluation of the effect of obesity on alveolar bone in rats with ligature-induced periodontal disease
}

This article was published in the following Dove Press journal:

Diabetes, Metabolic Syndrome and Obesity: Targets and Therapy 4 October 2013

Number of times this article has been viewed

\author{
Cassiane Merigo \\ do Nascimento' \\ Tiago Cassol ${ }^{2}$ \\ Fernanda Soares da Silva ${ }^{3}$ \\ Maria Lucia Bonfleur ${ }^{4}$ \\ Carlos Augusto Nassar ${ }^{5}$ \\ Patricia Oehlmeyer Nassar ${ }^{5}$ \\ 'Biologica Science and Health Center, \\ State University of West Paraná \\ (UNIOESTE), Cascavel, Paraná, Brazil; \\ ${ }^{2}$ State University of West Paraná \\ (UNIOESTE), Cascavel, Paraná, Brazil; \\ Department of ${ }^{3}$ Pharmacy, ${ }^{4}$ Fisiology, \\ ${ }^{5}$ Periodontology, Dental School, \\ State University of West Paraná \\ (UNIOESTE), Cascavel, Paraná, Brazil
}

Correspondence: Carlos Augusto Nassar Department of Periodontology, Dental School, State University of West Paraná (UNIOESTE), Rua Pernambuco 593, Apto 504, Centro 85810-020,

Cascavel, Paraná, Brazil

Tel +55 4591013369

Email canassar@yahoo.com

\begin{abstract}
There is evidence that the lack of metabolic control of obese patients may accelerate periodontitis. The aim of this study was to evaluate radiographically the effect of cafeteria-dietinduced obesity on alveolar bone loss in rats subjected to periodontal disease. Twenty male Wistar rats were randomly divided into four groups: 1) control group, 2) control and ligature group; 3) cafeteria group; and 4) cafeteria and ligature group. The animals were evaluated for obesity and euthanized, and the mandible of each rat was removed to perform a radiographic evaluation of alveolar bone loss and its effect on diet-induced obesity. The results showed greater alveolar bone loss in the mice in Group $4(P<0.01)$. Thus, we concluded that obese mice, on average, showed greater radiographic evidence of alveolar bone loss than mice undergoing induction of obesity.
\end{abstract}

Keywords: periodontal disease, radiography, obesity

\section{Introduction}

Obesity has reached epidemic proportions ${ }^{1}$ and is the fastest-growing health-related problem in the world. ${ }^{2}$ According to the World Health Organization, 1.5 billion adults are overweight, and, of these, 500 million are clinically obese. ${ }^{3}$ In Europe, the prevalence of obesity is between $10 \%$ and $25 \%$, while in the United States the rates vary between $25 \%$ and $35 \%{ }^{3,4}$ According to the Brazilian Ministry of Health, ${ }^{5}$ rates of overweight and obesity have increased over the last 6 years in Brazil. According to the Brazilian study, the proportion of overweight people increased from $42.7 \%$ in 2006 to $48.5 \%$ in 2011. Within that same period, obesity percentage increased from $11.4 \%$ to $15.8 \%{ }^{5}$ It is estimated that obesity and its complications are responsible for a significant number of deaths worldwide. ${ }^{3}$

To further understand the role of each of the elements involved in the pathophysiology of obesity, researchers have used experimental animal models that may determine in a controlled manner the role of each component of insulin secretion and peripheral resistance to insulin and obesity. Among the different models, there are those derived from the genetic strains caused by autosomal recessive mutations (Zucker fa/fa rats, ob/ob mice) as well as transgenic mice and knockouts for specific genes; rats and mice subjected to electrolytic lesions in hypothalamic regions (eg, ventral medial hypothalamus); specific drug-induced chemical injuries (monosodium glutamate); ${ }^{6}$ and animals subjected to hypercaloric and/or hyperlipidemic diets. ${ }^{7}$

Although the abovementioned experimental models characterize an important aspect of insulin resistance and obesity, the model that most resembles human obesity is exogenous obesity, in which the animal is offered a high-carbohydrate/ 
high-fat diet, either alone or in combination. ${ }^{7}$ This diet is called the Western, fast-food, or cafeteria diet, and has been shown to produce an increase in total body weight by approximately $30 \%-40 \%$ by the end of a 12 -week study, as well as an increase in visceral fat, resistance insulin, and hyperleptinemia. ${ }^{8}$

Several scientific studies have suggested that obesity contributes to the severity of periodontal disease..$^{9-12}$ Periodontitis is a chronic infectious disease caused predominantly by bacteria that release endotoxins that activate proinflammatory cytokines interleukin (IL)-1 and tumor necrosis factor alpha (TNF- $\alpha$ ), among other interleukins, which affect the tissues supporting the teeth and induce loss of alveolar bone, cementum, and periodontal ligament. ${ }^{13-15}$

Among the risk factors for periodontitis, obesity has received special attention in dentistry. Recent evidence suggests that adipose tissue is a reservoir of inflammatory cytokines. ${ }^{16-19}$ Since obesity and periodontitis are associated with systemic inflammation, it may be said that these two situations are linked by common pathophysiology. Thus, it is plausible that the increase of adipose tissue results in increased activation of the inflammatory host response, making the obese individual more susceptible to periodontal disease. The amount of evidence linking obesity to the occurrence and severity of periodontal disease has grown consistently in recent years. ${ }^{16-19}$

Saito et al showed that the increase in body mass index (BMI) and waist-hip ratio are associated with the development of periodontitis. ${ }^{12}$ Epidemiological data have shown that obese and insulin-resistant patients have high plasma concentrations of inflammatory markers. ${ }^{13,14}$ Adipose tissue secretes large amounts of TNF- $\alpha$ and IL- $6,{ }^{13}$ and the concentration of these cytokines is proportional to the BMI. ${ }^{14}$ Increased plasma concentrations of proinflammatory cytokines could explain the relationship between obesity and periodontal disease. ${ }^{15}$ The high concentration of TNF- $\alpha$ may exacerbate preexistent periodontal disease through the stimulation of fibroblasts that promote the synthesis of degrading enzymes and the stimulation of osteoclasts that activate bone resorption. ${ }^{15}$ The aim of this study was to evaluate radiographically the effect of cafeteria-diet-induced obesity on alveolar bone loss in rats subjected to periodontal disease.

\section{Materials and methods}

\section{Animals}

Twenty eight-week-old male Wistar rats were obtained from the animal colony of the State University of West Paraná (UNIOESTE), Cascavel, Brazil, and maintained in the vivarium section of the human physiology laboratory at this institution, under controlled light (12-hour/12-hour light/dark cycle, light from 7 am to $7 \mathrm{pm}$ ) and temperature $\left(21^{\circ} \mathrm{C} \pm 2{ }^{\circ} \mathrm{C}\right)$ conditions. The animals were randomly divided into four groups. The control group $(\mathrm{CON})$ received standard diet and water; the control and ligature group (CONLIG) received standard diet and water, but were subjected to ligature-induced periodontal disease; the cafeteria group (CAF) received cafeteria diet and soda for 24 weeks; and the cafeteria and ligature group (CAFLIG) received cafeteria diet and soda for 24 weeks, but were subjected to ligatureinduced periodontal disease. All experimental protocols were approved by the Ethics Committee on Animal Experimentation (CEUA) at UNIOESTE.

\section{Diet compositions}

Animals receiving the cafeteria diet were fed on modified food pellets containing $37.5 \%$ of standard ration, $25 \%$ roasted peanuts, $25 \%$ chocolate bar, and $12.5 \%$ cornstarch biscuit. The animals were also offered the following daily additional food: savory snacks, chocolate wafer, industrial cake, and soda without carbonation. The diet composition and calories were as follows: cafeteria diet, $5.4 \mathrm{kcal} / \mathrm{g}$ (38.5\% carbohydrates, $15 \%$ protein, and $46.5 \%$ fat); and standard diet, $3.8 \mathrm{kcal} / \mathrm{g}$ (70\% carbohydrates, $20 \%$ protein, and $10 \%$ fat).

\section{Animal weighing}

All animals were individually weighed once a week throughout the experimental period.

\section{Induced periodontal disease}

At 140 days of age, the animals were anesthetized (xylazine $0.04 \mathrm{~mL} / 100 \mathrm{~g}$ and ketamine $0.08 \mathrm{~mL} / 100 \mathrm{~g}$ ) and placed on a proper operating table, which allowed open-mouth maintenance of the rats to facilitate access to the teeth in the posterior mandibular region. With the aid of modified forceps and an exploratory probe, \#40 cotton thread was placed around the right mandibular first molar. This ligature acted as a gingival irritant for 30 days and promoted the accumulation of plaque and subsequent development of periodontal disease..$^{20}$

\section{Obesity evaluation}

At 170 days, the animals were weighed and the naso-anal length was obtained to calculate the Lee index:

cube root of body weight $(\mathrm{g}) /$ naso-anal length $(\mathrm{cm})$. [1] 
The animals were subsequently euthanized and periepididymal and retroperitoneal fat were removed and weighed.

\section{Radiographic analysis}

Immediately after they had been sacrificed, the mandible of each animal was removed and fixed in buffered formalin $(\mathrm{pH}$ 7.2) for 48 hours. The hemimandibles were placed with the lingual side on the periapical radiographic film (Dentus ${ }^{\circledR}$; Agfa-Gevaert NV, Mortsel, Belgium and Kodak ${ }^{\circledR}$ Ultraspeed; Eastman Kodak Company, Rochester, NY, USA) and placed in a way that the buccal and lingual cusps of the first molars remained on the same vertical plane. We used the GE 1000 X-ray machine (General Electric Company, Fairfield, CT, USA), exposing it at $15 \mathrm{~mA}, 65 \mathrm{Vp}, 18$ impulses, focus/film distance $50 \mathrm{~cm}$ with $\mathrm{X}$-ray incidence perpendicular to the pieces. To develop the films, we used Kodak ${ }^{\circledR}$ developer and fixer solution (Eastman Kodak Company), respecting the recommended time/temperature for film processing, then scanned the films using a scanner for slides (Sprint Scan 35 Plus; Polaroid, São Paulo, Brazil). The scanned images were analyzed in three steps using the Image Tool 3.0 program (The University of Texas Health Science Center, San Antonio, TX, USA), and the means were established through linear measurement, which covered the distance from the cementoenamel junction to the alveolar bone crest on the mesial side of the right mandibular first molar of the rat, displaying the measurements in pixels. ${ }^{20}$

\section{Statistical analysis}

The obtained data were analyzed and assessed by analysis of variance $(P<0.01)$ and Tukey's test was subsequently carried out on all data $(P<0.01)$.

\section{Results}

Table 1 shows the mean values of the final weights $(\mathrm{g})$, naso-anal length $(\mathrm{cm})$, and Lee index $(\mathrm{g} / \mathrm{cm})$ of rats in

Table I Values of final weight, naso-anal length, and Lee index of rats in the pre-established groups

\begin{tabular}{llll}
\hline Group & $\begin{array}{l}\text { Final weight } \\
(\mathbf{g})\end{array}$ & $\begin{array}{l}\text { Naso-anal } \\
\text { length }(\mathbf{c m})\end{array}$ & $\begin{array}{l}\text { Lee index } \\
(\mathbf{g} / \mathbf{c m})\end{array}$ \\
\hline CON & $472 \pm 1.0^{\mathrm{a}}$ & $24.0 \pm 1.0^{\mathrm{a}}$ & $320.7 \pm 15.0^{\mathrm{a}}$ \\
CONLIG & $460 \pm 2.0^{\mathrm{a}}$ & $24.0 \pm 1.0^{\mathrm{a}}$ & $316.9 \pm 10.0^{\mathrm{b}}$ \\
CAF & $630 \pm 5.5^{\mathrm{b}}$ & $25.5 \pm 1.0^{\mathrm{a}, \mathrm{b}}$ & $336.0 \pm 13.0^{\mathrm{c}}$ \\
CAFLIG & $618 \pm 2.5^{\mathrm{b}}$ & $26.4 \pm 1.0^{\mathrm{b}}$ & $322.0 \pm 11.0^{\mathrm{d}}$ \\
\hline
\end{tabular}

Notes: Data are presented as mean \pm standard deviation. $P<0.01$. ${ }^{a-d}$ Results were statistically different within the same parameter assessed.

Abbreviations: CON, control group; CONLIG, control and ligature group: CAF, cafeteria group; CAFLIG, cafeteria and ligature group. the pre-established groups. These results show that, on average, the rats became significantly obese with the cafeteria diet.

Table 2 shows the mean values of the weights of retroperitoneal and periependymal fat of the rats in the preestablished groups. These results show that, on average, there was a significant difference in weight between the groups with (CAF and CAFLIG) and without (CON and CONLIG) induction of obesity.

Table 3 shows the mean values obtained from the X-ray measurements. These results show significant difference in alveolar bone loss when comparing the groups with or without periodontal disease induced. Alveolar bone loss was particularly high in the CAFLIG group.

\section{Discussion}

Several studies have been conducted to investigate the relationship between obesity and several chronic degenerative diseases. ${ }^{11,21,22}$ Some studies show that obesity is a major risk factor for the host as it increases the risk of developing periodontal disease,,$^{11,21}$ but further research is required because literature is controversial in relation to the subject, ${ }^{22}$ which contributes to justifying the present study.

The results shown in Tables 1 and 2 present the effectiveness of the cafeteria diet proposed in our study on inducing obesity in experimental animals by means of the analysis of final weight, Lee index, and retroperitoneal and periependymal fat, demonstrating a significant difference between the values $(P<0.01)$, particularly when compared with the CON and CAF groups without ligature-induced periodontal disease. These results corroborate the studies of de Paula et $\mathrm{al}^{8}$ and Cesaretti and Kohlmann Junior, who showed that mice subjected to a carbohydrate and fat overload become obese, a diet that influences total body weight, leading to increased visceral fat, insulin resistance, and hyperleptinemia.

Table 2 Values of the weights of retroperitoneal and periependymal fat of established groups of mice

\begin{tabular}{|c|c|c|c|c|}
\hline \multirow[t]{3}{*}{$\overline{\text { Group }}$} & \multirow{2}{*}{\multicolumn{2}{|c|}{$\begin{array}{l}\text { Retroperitoneal fats } \\
\text { Weight }\end{array}$}} & \multirow{2}{*}{\multicolumn{2}{|c|}{$\begin{array}{l}\text { Periependymal fats } \\
\text { Weight }\end{array}$}} \\
\hline & & & & \\
\hline & (g) & (\%) & (g) & (\%) \\
\hline $\mathrm{CON}$ & $5.8 \pm 1.0^{\mathrm{a}}$ & $1.2 \pm 0.2^{\mathrm{a}}$ & $7.4 \pm 1.4^{\mathrm{a}}$ & $1.6 \pm 0.3^{a}$ \\
\hline CONLIG & $6.0 \pm 1.0^{\mathrm{a}}$ & $1.3 \pm 0.2^{\mathrm{a}}$ & $7.2 \pm 1.0^{\mathrm{a}}$ & $1.6 \pm 0.2^{\mathrm{a}}$ \\
\hline $\mathrm{CAF}$ & $30.6 \pm 4.0^{\mathrm{b}}$ & $4.8 \pm 0.5^{b}$ & $14.3 \pm 2.9^{b}$ & $2.3 \pm 0.4^{b}$ \\
\hline CAFLIG & $26.0 \pm 4.0^{\mathrm{b}}$ & $4.2 \pm 0.7^{b}$ & $14.4 \pm 1.8^{\mathrm{b}}$ & $2.3 \pm 0.2^{\mathrm{b}}$ \\
\hline
\end{tabular}

Notes: Data are presented as mean \pm standard deviation. $P<0.01$. ${ }^{a, b}$ Results were statistically different within the same parameter assessed.

Abbreviations: CON, control group; CONLIG, control and ligature group; CAF, cafeteria group; CAFLIG, cafeteria and ligature group. 
Table 3 Mean values of measurements of the distance from the cementoenamel junction to the alveolar crest of rats in the established groups

\begin{tabular}{ll}
\hline Group & Mean \pm standard deviation (pixels) \\
\hline CON & $112 \pm 0.7^{\mathrm{a}}$ \\
CONLIG & $140 \pm 0.5^{\mathrm{b}}$ \\
CAF & $129 \pm 0.4^{\mathrm{c}}$ \\
CAFLIG & $149 \pm 0.8^{\mathrm{d}}$ \\
\hline
\end{tabular}

Notes: $P<0.01$. ${ }^{a-d}$ Results were statistically different within the same parameter assessed.

Abbreviations: CON, control group; CONLIG, control and ligature group; CAF, cafeteria group; CAFLIG, cafeteria and ligature group.

These results may suggest the influence of fats in the development of periodontal disease when radiographically analyzed (Table 3 ). Adipose tissues are capable of producing a number of biologically active molecules in which different cytokines are found. ${ }^{23-25}$ Adipose tissues may therefore exhibit functional and immunological characteristics. ${ }^{23,24,26}$ Studies on tissue culture show that, when fat cells from obese mice are stimulated with lipopolysaccharide, they significantly increase the release of TNF- $\alpha$ compared with the fat cells in non-obese mice..$^{23,24}$ The large quantities of proinflammatory cytokines IL- 1 and TNF- $\alpha$, among other interleukins, released directly, affect the tissues supporting the teeth and induce loss of alveolar bone, cementum, and periodontal ligament, which influence and contribute to the increase or progression of periodontal disease.

Investigating the relationship between obesity, inflammation, insulin resistance, and periodontal disease, Genco et $\mathrm{a}^{26}$ noted that BMI was directly related to the development of periodontal disease, and that individuals with higher BMI showed higher levels of TNF- $\alpha$ and its receptors. This result shows the involvement of proinflammatory cytokines in the development of periodontal disease.

Furthermore, concerning the retroperitoneal and periepidimal fat and final weights, it is interesting to note that, when the same protocols were compared (comparison between the CON and CONLIG groups without induced obesity and comparison between the CAF and CAFLIG groups with induced obesity by cafeteria diet), there was a reduction in these parameters (final weights and fats) in groups in which periodontal disease was induced, although not statistically significant, which would suggest that the ligature, contributing to the development of periodontal disease, may have influenced the feeding behavior in the rat.

In this study, the results show that there was a statistically significant difference $(P<0.01)$ in alveolar bone loss between the groups, and the groups with ligatures lost more alveolar bone than their counterparts (Table 3 ). These results corroborate the experimental study of Perlstein and Bissada, ${ }^{11}$ who investigated the biological association between obesity and periodontal disease. The authors investigated whether obesity and/or hypertension may cause histological changes in the periodontium of rats in the presence or absence of ligature-induced periodontitis. They found that obese and/or hypertensive rats had higher attachment loss than the control group. Metabolic changes frequently observed in obese individuals may negatively affect the host immune-inflammatory response, ${ }^{27}$ causing a breach of homeostasis and reducing tissue repair capacity. ${ }^{28}$

In contrast, Simch et al ${ }^{22}$ evaluated the effect of overweight on alveolar bone loss in Wistar rats. Seventeen 60-day-old rats were randomly selected and exposed to the cafeteria diet intake for 120 days. After that, the rats were subjected to ligature placement for 30 days to induce periodontal disease. Alveolar bone loss was analyzed morphometrically. The results of the study showed no significant differences regarding induced alveolar bone loss among the rats with and without overweight. It is noteworthy that, in our study, the animals were exposed to a high-fat diet for 170 days, thus a longer period than in the studies of Simch et al, ${ }^{22}$ which may have contributed to alveolar bone loss in our study. In another study, Brandelero et $\mathrm{al}^{29}$ also showed that obesity had a protective effect when periodontal disease was induced in rats, which may be due to obesity having been induced by another experimental model.

Obesity seems to affect bone metabolism through multiple mechanisms. First, osteoblasts and adipocytes derive from a common mesenchymal cell in the bone marrow. Obesity can induce adipogenesis while decreasing osteoblastogenesis. ${ }^{30}$ Another mechanism by which obesity can affect bone metabolism is through receptor activator of NF-KB (RANK), RANK ligand (RANK-L), and osteoprotegerin $(\mathrm{OPG})$, by which osteoblasts are capable of regulating the differentiation and activity of osteoclasts. The overproduction of proinflammatory cytokines such as IL-1, IL- 6 , and TNF- $\alpha$ by adipocytes are capable of stimulating the activity of osteoclasts by regulating RANK/RANKL/ OPG. ${ }^{31}$ Adipocytes may also directly regulate hematopoietic progenitor cells of osteoclasts. ${ }^{32}$

The direct or indirect production of leptin and adiponectin related to obesity may influence bone metabolism. Circulating leptin levels are high in cases of obesity. The action of leptin on bone seems to be variable; ${ }^{33}$ however, it seems to negatively affect the bone metabolism of animals subjected to high-fat-diet-induced obesity. ${ }^{34}$ With regard to adiponectin, it has been observed that cytokine secreted by 
adipocytes has an anti-inflammatory action which is associated with the reduction of osteoclastogenesis, bone resorption, and stimulation of osteoblastogenesis. ${ }^{35}$ However, the plasma concentration of this cytokine is decreased in obese compared with non-obese individuals. ${ }^{36}$ Finally, the calcium absorption seems to be diminished in the presence of highfat diets. ${ }^{34}$

Since obesity is a disease with systemic characteristics, we can infer that the effects of obesity on bone tissue act on the periodontal tissues and alveolar bone, which is in agreement with the results of the present study, which found that the association of obesity and periodontal disease contributed to greater alveolar bone loss in the animals.

\section{Conclusion}

Within the limits of our experimental study, it may be concluded that cafeteria diet induced obesity led to greater alveolar bone loss in obese rats, as assessed radiographically, suggesting that obesity can contribute to further progression of periodontal disease.

\section{Disclosure}

The authors report no conflicts of interest in this work.

\section{References}

1. James PT, Rigby N, Leach R; International Obesity Task Force. The obesity epidemic, metabolic syndrome and future prevention strategies. Eur J Cardiovasc Prev Rehabil. 2004;11(1):3-8.

2. Haenle MM, Brockmann SO, Kron M, et al; EMIL-Study group. Overweight, physical activity, tobacco and alcohol consumption in a cross-sectional random sample of German adults. BMC Public Health. 2006;6:233.

3. WHO Global InfoBase [webpage on the Internet]. Geneva: World Health Organization; 2010 [updated January 20, 2011]. Available from: http://www.who.int/infobase/report.aspx?rid=116\&dm=5\&iso=ZZZ\& searchButton=SearSurveys. Accessed December 3, 2012.

4. Ogden CL, Carroll MD, Curtin LR, McDowell MA, Tabak CJ, Flegal KM. Prevalence of overweight and obesity in the United States, 1999-2004. JAMA. 2006;295(13):1549-1555.

5. [Almost half of the population is overweight] [webpage on the Internet]. Brazil Ministry of Health; 2012. Available from: http:// portalsaude.saude.gov.br/portalsaude/noticia/4718/162/quasemetade-da-populacao-brasileira-esta-acima-do-peso.html. Accessed November 28, 2012. [Portuguese].

6. Bray GA, York DA. Hypothalamic and genetic obesity in experimental animals: an autonomic and endocrine hypothesis. Physiol Rev. 1979;59(3):719-809.

7. Cesaretti ML, Kohlmann Junior O. Experimental models of insulin resistance and obesity: lessons learned. Arq Bras Endocrinol Metabol. 2006;50(2):190-197. Portuguese.

8. de Paula RB, da Silva AA, Hall JE. Aldosterone antagonism attenuates obesity-induced hypertension and glomerular hyperfiltration. Hypertension. 2004;43(1):41-47.

9. Lösche W, Karapetow F, Pohl A, Pohl C, Kocher T. Plasma lipid and blood glucose levels in patients with destructive periodontal disease. J Clin Periodontol. 2000;27:537-541.

10. Iacopino AM. Periodontitis and diabetes interrelationships: role of inflammation. Ann Periodontol. 2001;6:125-137.
11. Perlstein MI, Bissada NF. Influence of obesity and hypertension on the severity of periodontitis in rats. Oral Surg Oral Med Oral Pathol. 1977;43:707-719.

12. Saito T, Murakami M, Shimazaki Y, Oobayashi K, Matsumoto S, Koga T. Association between alveolar bone loss and elevated serum C-reative protein in Japanese men. J Periodontol. 2003;74: $1741-1746$.

13. Orban Z, Remaley AT, Sampson M, Trajanoski Z, Chrousos GP. The differential effect of food intake and beta-adrenergic stimulation on adipose-derived hormones and cytokines in man. J Clin Endocrinol Metab. 1999;84:2126-2133.

14. Vgontzas AN, Papanicolaou DA, Bixler EO, Kales A, Tyson K, Chrousos GP. Elevation of plasma cytokines in disorders of excessive daytime sleepness: role of sleep disturbance and obesity. J Clin Endocrinol Metab. 1977;82:1313-1316.

15. Bastos AA, Falcão CB, Pereira ALA, Pereira AFV, Alves CMC. Obesity and periodontal disease. Pesqui Bras Odontopediatria Clin Integr. 2005;5:275-279. Portuguese, English.

16. Dalla Vecchia CF, Susin C, Rösing CK, Oppermann RV, Albandar JM. Overweight and obesity as risk indicators for periodontitis in adults. J Periodontol. 2005;76(10):1721-1728.

17. Bouchard P, Boutouyrie P, Mattout C, Bourgeois D. Risk assessment for severe clinical attachment loss in an adult population. J Periodontol. 2006;77(3):479-489.

18. Iacopino AM. Relationship between obesity and periodontal disease: increasing evidence. J Can Dent Assoc. 2009;75(2):92-93.

19. Gorman A, Kaye EK, Apovian C, Fung TT, Nunn M, Garcia RI. Overweight and obesity predict time to periodontal disease progression in men. J Clin Periodontol. 2012;39(2):107-114.

20. Nassar CA, Nassar PO, Abi Rached RS, Holzhausen M, Marcantonio E Jr, Spolidorio LC. Effect of cyclosporin A on alveolar bone homeostasis in a rat periodontitis model. $J$ Periodontol Res. 2004;39:143-148.

21. Verzeletti GN, Gaio EJ, Linhares DS, Rösing CK. The effect of obesity on alveolar bone loss in Wistar rats. J Appl Oral Sci. 2012;20(2): 218-221.

22. Simch RP, Gaio EJ, Rosing CK. Effect of body weight in the pathogenesis of ligature-induced periodontal disease in Wistar rats. Acta Odontol Scand. 2008;66(3):130-134.

23. Coppack SW. Pro-inflammatory cytokines and adipose tissue. Proc Nutr Soc. 2001;60(3):349-356.

24. Duncan BB, Schmidt MI. Chronic activation of the innate immune system may underlie the metabolic syndrome. Sao Paulo Med J. 2001;119(3):122-127.

25. Saito T, Shimazaki Y. Metabolic disorders related to obesity and periodontal disease. Periodontol 2000. 2007;43:254-266.

26. Genco R, Grossi SG, Ho A, Nishimura F, Murayama Y. A proposed model linking inflammation to obesity, diabetes, and periodontal infections. J Periodontol. 2005;76(Suppl 11):2075-2084.

27. Iacopino AM, Cutler CW. Pathophysiological relationships between periodontitis and systemic disease: recent concepts involving serum lipids. J Periodontol. 2000;71(8):1375-1384.

28. Iacopino AM. Diabetic periodontitis: possible lipid-induced defect in tissue repair through alteration of macrophage phenotype and function. Oral Dis. 1995;1(4):214-229.

29. Brandelero S Jr, Bonfleur ML, Ribeiro RA, et al. Decreased TNF- $\alpha$ gene expression in periodontal ligature in MSG-obese rats: a possible protective effect of hypothalamic obesity against periodontal disease? Arch Oral Biol. 2012;57(3):300-306.

30. Zhao LJ, Jiang H, Papasian CJ, et al. Correlation of obesity and osteoporosis: effect of fat mass on the determination of osteoporosis. $J$ Bone Min Res. 2008;23(1):17-29.

31. Khosla S. Minireview: the OPG/RANKL/RANK system. Endocrinology. 2001;142(12):5050-5055.

32. Naveiras O, Nardi V, Wenzel PL, Hauschka PV, Fahey F, Daley GQ. Bone-marrow adipocytes as negative regulators of the haematopoietic microenvironment. Nature. 2009;459(7250):1131-1135. 
33. Ducy $\mathrm{P}$, Amling M, Takeda S, et al. Leptin inhibits bone formation through a hypothalamic relay: a central control of bone mass. Cell. 2000;100(2):197-207.

34. Cao JJ, Sun L, Gao H. Diet-induced obesity alters bone remodeling leading to decreased femoral trabecular bone mass in mice. Ann NY Acad Sci. 2010;1192:292-297.
35. Oshima K, Nampei A, Matsuda M, et al. Adiponectin increases bone mass by suppressing osteoclast and activating osteoblast. Biochem Biophys Res Commun. 2005;331(2):520-526.

36. Arita Y, Kihara S, Ouchi N, et al. Paradoxical decrease of an adiposespecific protein, adiponectin, in obesity. Biochem Biophys Res Commun. 1999;257(1):79-83.

\section{Publish your work in this journal}

Diabetes, Metabolic Syndrome and Obesity: Targets and Therapy is an international, peer-reviewed open-access journal committed to the rapid publication of the latest laboratory and clinical findings in the fields of diabetes, metabolic syndrome and obesity research. Original research, review, case reports, hypothesis formation, expert opinion and commentaries are all considered for publication. The manuscript management system is completely online and includes a very quick and fair peer-review system, which is all easy to use. Visit http://www.dovepress.com/testimonials.php to read real quotes from published authors.

Submit your manuscript here: http://www.dovepress.com/diabetes-metabolic-syndrome-and-obesity-targets-and-therapy-journal 